\title{
離間と降伏を考慮した木造めり込み式の導出と簡易モデル化手法 FORMULATION AND SIMPLE MODELING METHOD OF EMBEDDING STIFFNESS AND STRENGTH OF TIMBER STRUCTURE CONSIDERING SEPARATION AND YIELD
}

\author{
望月 英二* \\ Eiji MOCHIZUKI
}

\begin{abstract}
The embedment in orthogonal direction of fibers is a major structural element of timber structures. The relationship between axial force and bending moment considering geometric separation of members and yield of material is discussed and some formulae for analyses are derived. A simple modeling method for analysis is devised from the formulae. Comparison between results of an experiment and elasto-plastic analyses in keeping with the method shows the effectiveness and the limitation of the formulae and the method.
\end{abstract}

Keywords : Timber structure, Formulation, Embedding stiffness and strength, Geometric separation and yield, Simple analysis model 木造構造物, 定式化, めり込み, 離間と降伏, 簡易解析モデル

\section{1. はじめに}

伝統木造建物では木材の繊維直交方向のめり込みが主要な耐震要 素となることがある。めり込み自体に関する研究は、本邦において は、山井による研究を嚆矢に以降脈々となされ、設計にも広く使わ れている稲山によるめり込み理論 1)や、近年の棚橋、鈴木らによる 弾塑性パステルナーク・モデルによるめり込み理論 2)などに続いて いる。めり込みは接触長さが重要なパラメータであり、通し貫に関 しては、回転に伴う離間を考慮した研究 3)が発表されている。しか しながら、斗組や柱と台輪の接合部などのように、軸力とモーメン トとが相互に無関係に変動する場合に関しては、木材同士の離間を 考慮した計算式はまだ提唱されていない。離間に関しては、これを 考慮できる解析方法として拡張個別要素法などがあり、木造でもそ

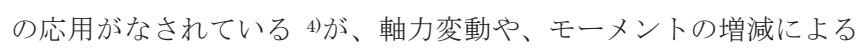
めり込み面の変動を考慮しためり込み回転剛性にまでは触れておら ず、また、解析方法としても現在の構造設計者にとって普遍的なも のとまでは言えない。そこで、本論文では、稲山によるめり込み理 論を基に、構造解析でも利用できるような離間と降伏を考慮しため り込み関係式を導出し、さらに一般的な解析手法でも利用できるよ うな簡易なモデル化手法を作成する。また、これに基づいた解析と 既往の実験と比較により、その有用性と限界について述べる。

\section{2. 離間を伴う場合のめり込み理論の課題}

稲山のめり込み理論は図 1 のモデルをもとに構成されており、等 変位めりこみの場合と、三角形変位めり込みに区分される。また、 その式は文献 1)から展開され、文献 5)では、図1の寸法でのめり込 みに対し、表 1 として表現されている（添え字は変えている）。そ
の他、降伏後の剛性の計算式が文献 1)では提示されているが、文献 5)では完全弾塑性として降伏後剛性なしとしているなどの違いがあ るが、文献 5)の式が広く使われていることから、今後の検討はこれ に沿ったものとする。

本研究の土台としているめり込み理論は、木材の特性をよく表現 した有用なものであるが、等変位めり込み、三角形変位めりこみと もに鋼板と木材の接触長さが一定の場合の式となっていること及び、 三角形変位めり込みではモーメント計算芯が構造解析で用いる部材 芯と同一ではないことから、鋼板の長さが変動する場合（=片端が 離間する場合)、および三角形変位めり込みのモーメント計算芯でな く部材芯を使用する線材による応力解析の場合には、そのままでは めり込み理論を利用できない。そこで、この両者を解決できる数式 化を試みる。

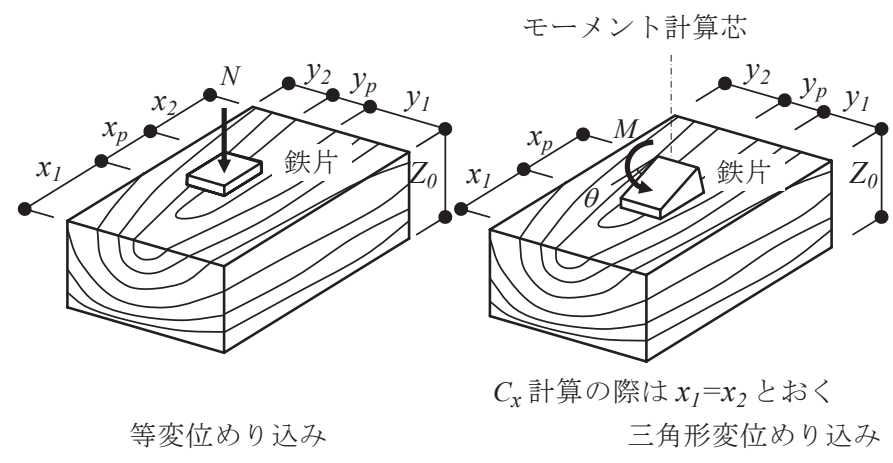

図 1 めり込み理論に使用する寸法

\footnotetext{
* (侏竹中工務店東京本店設計部構造部門 課長代理 ·工修 Manager, Structural Engineering Section, Building Design Department, Tokyo Main Office, Takenaka Corporation, M. Eng.
} 


\begin{tabular}{|c|c|c|}
\hline$N_{\text {等変位 }}=\frac{x_{p} y_{p} C_{x} C_{y} E_{\perp}}{Z_{0}} \delta_{\text {等变位 }}, \delta_{\text {等変位 }}$ & $=\frac{Z_{0} F_{m}}{E_{\perp} \sqrt{C_{x} C_{y} C_{x m} C_{y m}}}$ & $(1),(2)$ \\
\hline$N_{\text {三角 }}=\frac{x_{p}{ }^{2} y_{p} C_{y} E_{\perp} \theta}{Z_{0}}\left[\frac{1}{2}+\frac{2 Z_{0}}{3 x_{p}} \times(1-\right.$ & $\left.\left.e^{-\frac{3 x_{1}}{2 Z_{0}}}\right)\right]$ & (3) \\
\hline$M_{\text {三角 }}=\frac{x_{p}{ }^{3} y_{p} C_{y} E_{\perp} \theta}{Z_{0}}\left[\frac{1}{3}+\frac{2 Z_{0}}{3 x_{p}} \times(1-\right.$ & $\left.\left.e^{-\frac{3 x_{1}}{2 Z_{0}}}\right)\right]$ & (4) \\
\hline$\theta_{y \text { 三角 }}=\frac{Z_{0} F_{m}}{x_{p} E_{\perp} \sqrt{C_{x} C_{y} C_{x m} C_{y m}}}$ & & (5) \\
\hline$C_{x}=1+\frac{2 Z_{0}}{3 x_{p}} \times\left(2-e^{-\frac{3 x_{1}}{2 Z_{0}}}-e^{-\frac{3 x_{2}}{2 Z_{0}}}\right)$ & $C_{x_{m}}=1+\frac{4 Z_{0}}{3 x_{p}}$ & $(6),(7)$ \\
\hline$C_{\mathrm{y}}=1+\frac{2 Z_{0}}{3 \text { ny }_{p}} \times\left(2-e^{-\frac{3 n y_{1}}{2 Z_{0}}}-e^{-\frac{3 n y_{2}}{2 Z_{0}}}\right)$ &,$C_{y_{m}}=1+\frac{4 Z_{0}}{3 n y_{p}}$ & $(8),(9)$ \\
\hline \multicolumn{3}{|c|}{$E_{\perp}:$ 全面横圧縮ヤング係数 $\left(E_{\perp}=1 / 50 E_{0}\right)$} \\
\hline \multicolumn{3}{|l|}{$E_{O}:$ 繊維方向基準弾性係数 } \\
\hline \multicolumn{3}{|c|}{$n:$ 繊維方向に対する繊維直交方向の置換係数 $(n=5 \sim 7)$} \\
\hline \multicolumn{3}{|c|}{$\begin{array}{l}F m \text { : 縁端距離を無限大にしたときのめり込み降伏応力度 } \\
\quad\left(=0.8 \times F_{c v}\right)\end{array}$} \\
\hline \multicolumn{3}{|l|}{$F_{c v}:$ 材中間部部分圧縮基準材料強度 } \\
\hline $\begin{array}{l}N, M, \delta, \theta \text { における添え字 (等変位、三角 } \\
\text { みおよび三角形変位めり込みを表す }\end{array}$ & ）はそれぞれ、等匈 & めり込 \\
\hline
\end{tabular}

\section{3. 離間を考慮しためり込み式の展開}

\section{1 降伏を考慮しない場合}

問題を簡単にするために、まずめり込み降伏がないと仮定した場 合の検討を行う。前述したように、めり込みの基準式では、構造解 析における部材の位置（部材の中心）における曲げモーメントと違 う位置を計算芯としている。そのため、部材芯のモーメントを導く 必要がある。部材芯廻りのモーメント $M$ と軸力 $N$ を直接与えること により変形状態を計算することは困難である。そこで、接触状況に よるケース分けを行う。鋼板全体が接触し、かつ三角形変位めりこ みだけが生じる場合（ケース 1 ）の軸力とモーメントの関係を計算 し、この軸力を不変とし、モーメントがこれを上回る場合をケース
2、下回る場合をケース 3 とする（図 2)。

\section{(1) ケース 1 の場合}

三角形変位めり込みのみであるため、 $N$ 三角 $=N$ となる。式(3)から

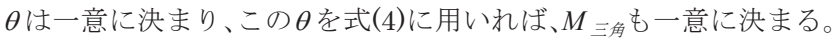
$\theta$ と $x_{p}(=L)$ から、部材芯の鉛直方向変位 $\delta$ が以下のように計算される。 $\delta=\left(x_{p}-L / 2\right) \times \theta=L / 2 \times \theta$

部材芯のモーメント $M$ は

$$
M=M_{\text {三角 }}+N_{\text {三角 }} \times\left(L / 2-x_{p}\right)
$$

と計算され、この関係式はケースに関わらず恒等的である。

(2) ケース 2 の場合

ケース 1 と同様に三角形変位めり込みのみのため、 $N$ 三角 $=N$ とな る。モーメント $M$ に応じて $x_{p}$ が変化するため、ケース 1 以上の $M$ 三角を仮定し、そこから、変形角を求める。

式(4)の両辺を式(3)で除す。その際に、

$$
\frac{M_{\text {三角 }}}{N_{\text {三角 }}}=a,\left(1-e^{-\frac{3 x_{1}}{2 Z_{0}}}\right)=b \text { とおくと、 } a=\frac{x_{p}\left(\frac{1}{3}+\frac{2 Z_{0}}{3 x_{p}} \times b\right)}{\frac{1}{2}+\frac{2 Z_{0}}{3 x_{p}} \times b}
$$

これを $x_{p}$ で整理すると、

$$
\frac{1}{3} x_{p}^{2}+\left(-\frac{1}{2} a+\frac{2 Z_{0}}{3} \times b\right) x_{p}-\frac{2 Z_{0}}{3} \times a b=0
$$

2 次方程式であるから、下式より実数となり、また、形状より、 $x_{p}$ は正の值をとる。

$$
\left(-\frac{1}{2} a+\frac{2 Z_{0}}{3} \times b\right)^{2} \leqq\left(-\frac{1}{2} a+\frac{2 Z_{0}}{3} \times b\right)^{2}+4 \times \frac{1}{3} \times \frac{2 Z_{0}}{3} \times a b
$$

$x_{p}$ が定まるので、ケース 2 と同様に、式(3)または(4)より、 $\theta$ が 一意に決まる。 $\theta$ と $x_{p}$ から、以下のように、部材芯の鉛直方向変位 放計算される。

$$
\delta=\left(x_{p}-L / 2\right) \times \theta
$$

$\delta$ の值は、 $x_{p}$ が $L / 2$ 未満となる場合は、軸力 $N$ が下向きであるに も関わらず上向きとなり、鉛直方向負剛性を表す。部材芯のモーメ ント $M$ は式(10)により計算される。

上記の $a$ を式(10)に代入すると、

$$
\begin{aligned}
& M=a \times N_{\text {三角 }}+N_{\text {三角 }} \times\left(L / 2-x_{p}\right) \\
& =N_{\text {三角 }} \times\left(a+L / 2-x_{p}\right)
\end{aligned}
$$

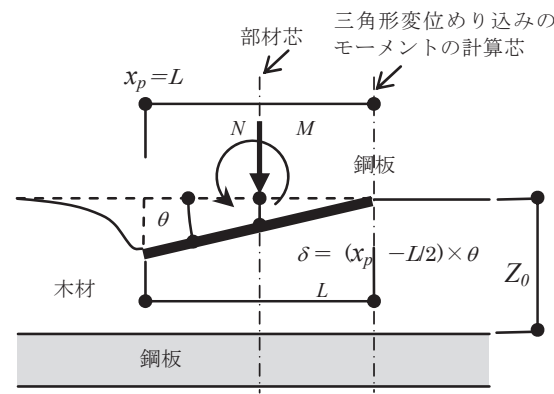

ケース 1

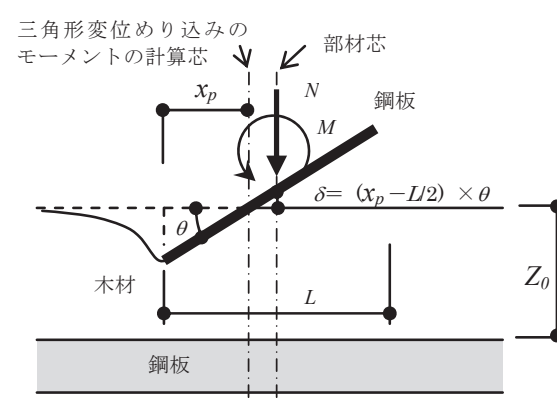

ケース 2

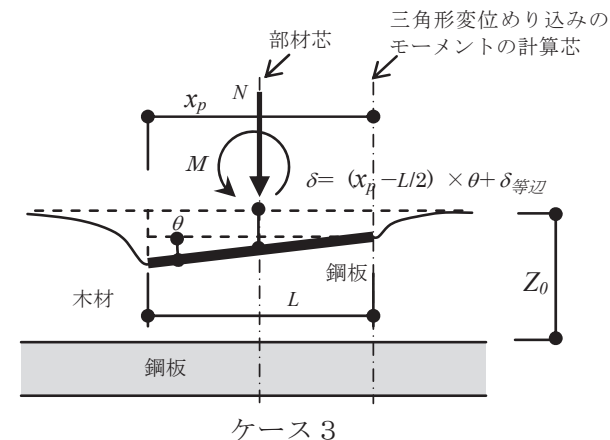

図 2 めり込多状態のケース分け 
(3) ケース 3 の場合

ケース 3 は、等変位めりこみと三角形変位めり込みの合成である。 $N$ を一定としたとき、 $N$ 三角と $N$ 等変位に分ける必要がある。ケース 2 と同様に $M_{\text {三角 }} / N_{\text {三角 }}=a$ とすると、 $x_{p}=L$ であるから、式(10)を展 開し、

$$
M=N_{\text {三角 }} \times(a-L / 2)
$$

となる。 $a-L / 2$ は形状により一定なので、 $N$ 三触 $M$ から計算され、 式(3)に $x_{p}=L$ を代入し、 $\theta$ が計算される。 $N$ 等変位 $=N-N$ 三角が等変位 めり込みに寄与し、式(1)に $N$ 等変位を代入することにより、等変位め り込みによる鉛直めり込み量 $\delta$ 等変位が計算できる。 $\theta$ および $\delta$ 等変位か ら、三角形変位めり込みと等変位めり込みによる部材芯の変形 $\delta$ 以゙以 下のように計算される。

$$
\delta=\left(x_{p}-L / 2\right) \times \theta+\delta \text { 等変位 }
$$

以上により、 $M, N, \delta, \theta$ の関係が求められる。

計算例として、 $L=y_{p}=\mathrm{Z}_{0}=10 \mathrm{~cm} 、 y_{1}=y_{2}=0 \mathrm{~cm}$ 、樹種をひのき $(n=6$, $\left.E_{0}=9000 \mathrm{~N} / \mathrm{mm}^{2}\right)$ とした場合の、 $x_{1}=x_{2}=0 \mathrm{~cm} 、 x_{1}=x_{2}=100 \mathrm{~cm}$ の 2 ケースの $M-\theta$ 関係を図 3 に示す。計算された等変位めり込み降伏 耐力は $40.5 \mathrm{kN} 、 56.4 \mathrm{kN}$ である。軸力は $N=7.5,15,30 \mathrm{kN}$ とした。 図中の太線はモーメントの理論上最大值（軸力が端部に集中した状 態）を示しており、 $M=L / 2 \times N$ である。どちらの場合も、変形 が進むにつれ、理論上最大值に近づき、 $x_{1}, x_{2}$ の寸法により剛性が 異なることが分かる。
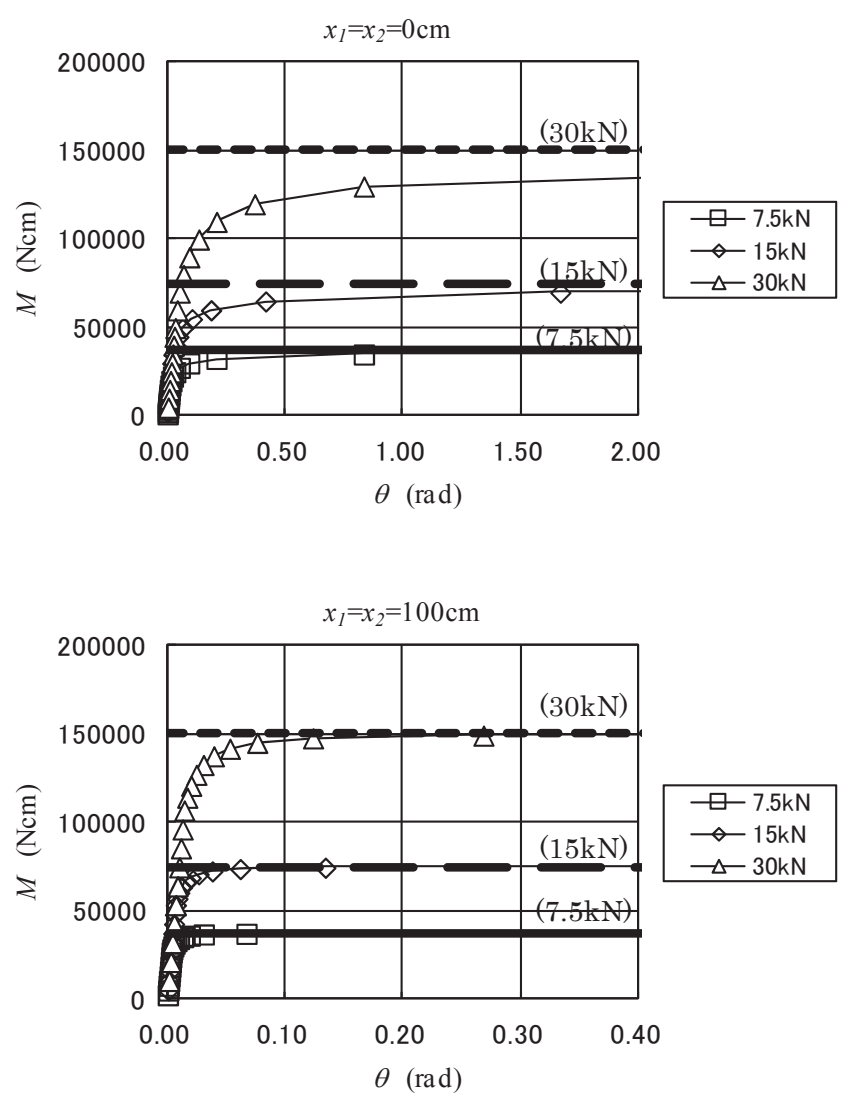

図 $3 M-\theta$ 関係 (降伏無視)

\section{2 降伏の考慮}

等変位めり込多における降伏変位 $\delta_{\text {、 }}$ 、三角形変位めり込みの降伏 変形角 $\theta_{y}$ は式(2),(5)のように規定されている。また、両式において、
$C_{x}$ を同一とすると、 $\delta_{y}$ 等変位 $=x_{p} \times \theta_{y}$ 三角となる。これは、等変位めり 込みの降伏変位から三角形変位めり込みの端部の降伏変位を定めた ためである 1)。すなわち、等変位めり込み十三角形変位めり込みの 状態においても、端部の降伏変位が降伏変位となる状態が降伏であ り、それ以上は塑性化が進展すると考えられる。

降伏を考慮するために、まず、 $x_{p}=L$ とした場合の等変位めり込み の降伏変位 $\delta_{y}$ の值を式(2)に代入し、最大の軸力 $N_{\max }$ 老計算寸る。

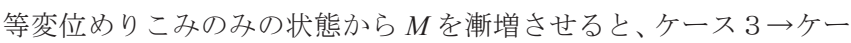
ス $1 \rightarrow$ ケス 2 となる。 $N$ が小さい場合、ケース 2 の段階に至って から、端部が降伏変位に到達する。 $N$ が大きい場合、ケース 3 の状 態で端部が降伏変位となり、ケース 1 、ケース 2 では常に塑性状態 となる。従って、ケース 1 の状態で降伏変位となっている否かで場 合分けをする。

(1) ケース 1 の状態における降伏変位

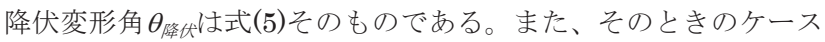
1 の状態の最大めり込み量は三角形変位めり込みの左端めり込み量

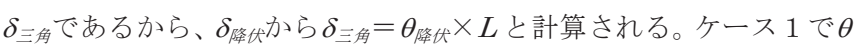

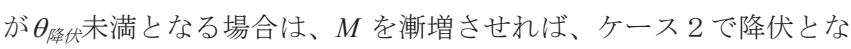

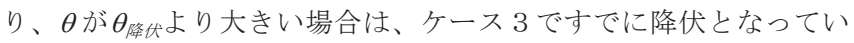
る。

（2) ケース 2 の変形状態で降伏変位となる場合 式(3)に式(5)を代入する。

$$
N_{\text {三角 }}=x_{p} y_{p} C_{y} \frac{F_{m}}{\sqrt{C_{x} C_{y} C_{x m} C_{y m}}}\left[\frac{1}{2}+\frac{2 Z_{0}}{3 x_{p}} \times\left(1-e^{-\frac{3 x_{1}}{2 Z_{0}}}\right)\right]
$$

三角形変位めり込みであるので、式(6)に $x_{l} x_{2}$ を代入すると、上式 の [] 内は $C_{x}$ となる。二乗し整理すると、下式になる。

$$
\frac{4 C_{y m} N_{\text {三角 }}^{2}}{y_{p}{ }^{2} C_{y} F_{m}{ }^{2}}=\frac{x_{p}{ }^{2} C_{x}}{C_{x m}}
$$

$C_{y m}, N$ 三解, $y_{p}, C_{y}, F_{m}$ は既知であるので、左辺 $=c$ とおき、式(6),(7)（た だし $\left.x_{1}=x_{2}\right)$ を代入して、

$$
c+\frac{4 c Z_{0}}{3 x_{p}}=x_{p}^{2}+\frac{4 x_{p} Z_{0}}{3} \times\left(1-e^{-\frac{3 x_{1}}{2 Z_{0}}}\right)
$$

$$
x_{p}^{3}+\frac{4 Z_{0}}{3} \times\left(1-e^{-\frac{3 x_{1}}{2 Z_{0}}}\right) x_{p}{ }^{2}-c x_{p}-\frac{4 c Z_{0}}{3}=0
$$

この 3 次方程式を解くことにより降伏開始時の $x_{p}$ が計算される。

(3) ケース 3 の変形状態で降伏変位となる場合

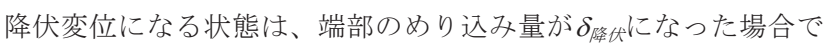

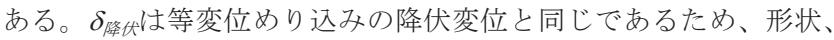
材質から計算できる。次に、三角形変位めり込みの端部めり込み量 $\delta$

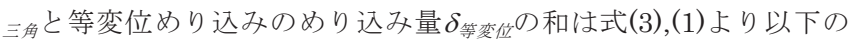
ように計算される。

$$
=\frac{\delta_{\text {三角 }}+\delta_{\text {等交位 }}}{x_{p} y_{p} C_{y} E_{\perp}\left[\frac{1}{2}+\frac{2 Z_{0}}{3 x_{p}} \times\left(1-e^{-\frac{3 x_{1}}{2 Z_{0}}}\right)\right]} N_{\text {三角 }}+\frac{Z_{0}}{x_{p} y_{p} C_{x} C_{y} E_{\perp}} N_{\text {等变位 }}
$$


$C x$ は三角形変位めり込みでは $x_{2}=x_{1}$ である。等変位めり込みではそ の規定はないが、同様に $x_{2}=x_{1}$ と仮定する。式(6)に $x_{2}=x_{1}$ を代入す ると、式(13)は、

$$
\begin{aligned}
\delta_{\text {三角 }}+\delta_{\text {等变位 }} & =\frac{Z_{0}}{x_{p} y_{p} C_{x} C_{y} E_{\perp}}\left(2 N_{\text {三角 }}+N_{\text {等变度位 }}\right) \\
& =\frac{Z_{0}}{x_{p} y_{p} C_{x} C_{y} E_{\perp}}\left(N+N_{\text {三角 }}\right)
\end{aligned}
$$

となる。降伏する場合は、 $\delta_{\text {降伏 }}=\delta_{\text {三角 }}+\delta_{\text {等変位 }}$ となるので、

$$
\delta_{\text {降伏 }}-\frac{Z_{0}}{x_{p} y_{p} C_{x} C_{y} E_{\perp}} N=\frac{Z_{0}}{x_{p} y_{p} C_{x} C_{y} E_{\perp}} N_{\text {三角 }}
$$

となる。ケース 3 では $x_{p}=L$ であり、左辺全ておよび右辺の $N_{\text {三角 }}$ 以外は計算できるので、 $N$ 三角が一意に決まる。 $N$ 三角より $\theta$ を計算し、 $M$ 三角を計算する。 $M_{\text {三角 }} / N_{\text {三角 }}=a$ と寸ると、 $M=N_{\text {三角 }} \times(a-L / 2)$ と なるので、降伏となる $M$ が計算できる。このようにして降伏を考慮 した場合の $M-\theta$ 関係を図 4 に示す。どちらの図も、降伏を考慮し ない場合と比較して、小さい值となっている。特に $x_{1}=x_{2}=0 \mathrm{~cm}$ の場 合は、めり込みの耐力が小さく計算されるため、降伏の影響が大き く、降伏無視の場合とは逆に $30 \mathrm{kN}$ の軸力のモーメントが最も小さ い結果となる。
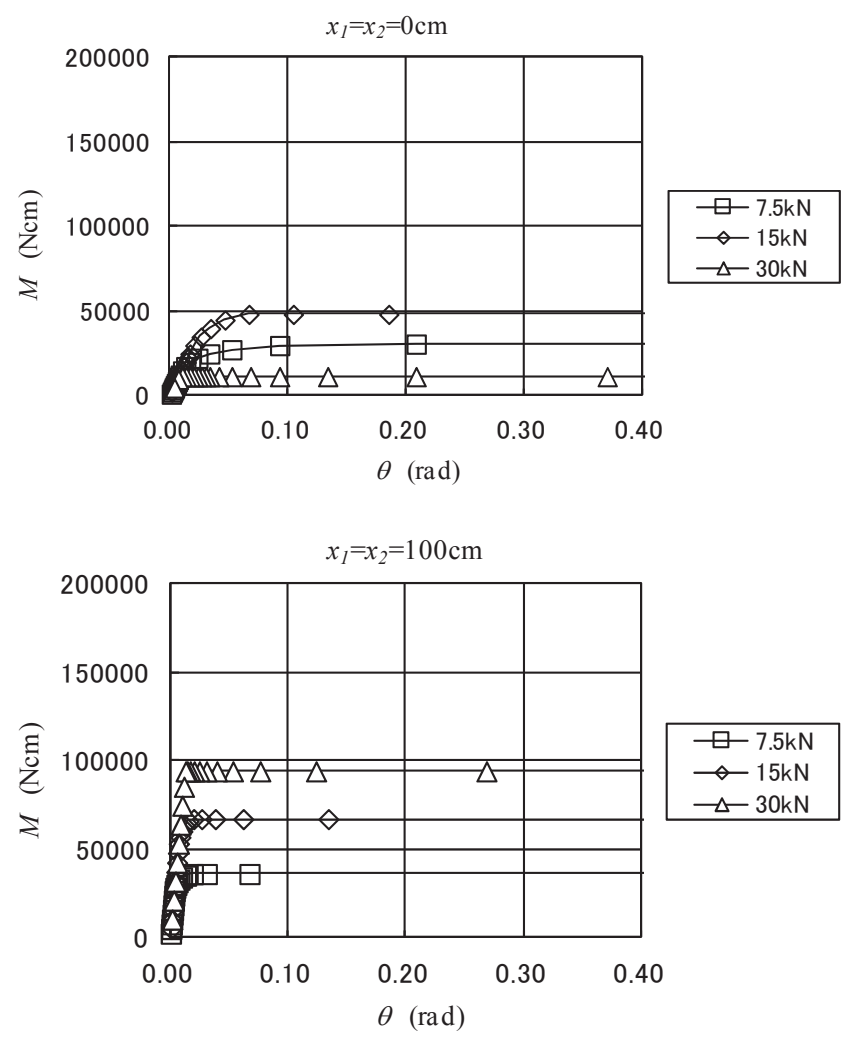

図 $4 \quad M-\theta$ 関係 $($ 降伏考慮)

\section{4. 解析モデルへの組み込み}

以上の結果を解析モデルに組み込む方法について述べる。解析に 用いる際は、できるだけ簡略化されたモデルが望ましいため、図 5 のようなモデルとする。立体解析に応用寸ることを考慮し、鉛直バ
ネ $k v$ は、図面上奥行き方向に $m$ 個配置することとする。従って、 鉛直バネ $k v$ は $2 \mathrm{~m}$ 個存在している。鉛直バネに摩擦係数を付加し、 接触問題を解くことができる解析ソフトの場合は、水平バネを用い ないことも考えられるが、めり込みによる形状変化も考慮した摩擦 係数を考慮する必要があり、煩雑となるため、静止摩擦以下の応力 を考え、めり込み接触面の水平バネは剛なバネとする。

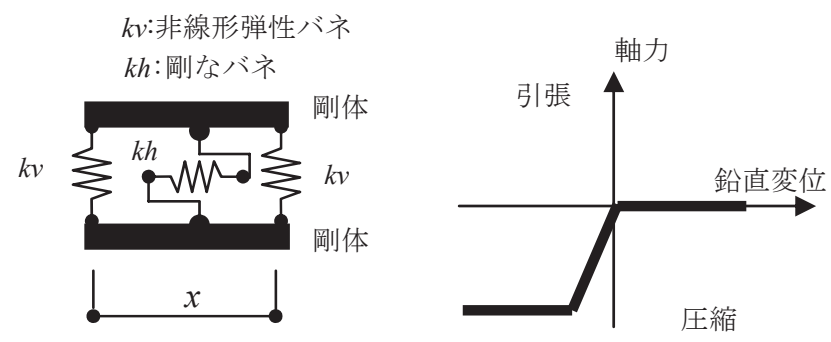

※これ以外にもねじれに関するバネが必要である。

図 5 モデル化の概念図

$N$ に応じて $M-\theta$ 関係が変わることは、以下のようにモデル化す る。式(1)より等変位めり込みによる剛性 $K$ 等変位が式(16)のように計 算される。

$$
K_{\text {等変位 }}=\frac{x_{p} y_{p} C_{x} C_{y} E_{\perp}}{Z_{0}}
$$

等変位めり込みでは、 $x_{p}=L$ となり、 $k v$ は $K$ 等変位の $2 m$ 等分なの で、式(17)で計算される。

$$
k v=\frac{1}{2 m} \cdot \frac{L y_{p} C_{x} C_{y} E_{\perp}}{Z_{0}}
$$

$N_{i n i}$ (圧縮を正とする) が与えられると、左右の変形は等しく、 $\delta_{i n i}=N_{i n i} / 2 m / k v$ と計算される。この状態に対し、 $M$ を漸増させると、 $M=\Delta N \times x \times m=k v \Delta \delta \times x \times m$ となる。また、そのとき、 $\theta=\Delta \delta /(x / 2)$ となる。従って、

$$
M=\frac{1}{2} \cdot k v \cdot \theta \cdot x^{2} \cdot m=\frac{1}{4} \cdot \frac{L y_{p} C_{x} C_{y} E_{\perp}}{Z_{0}} \cdot \theta \cdot x^{2}
$$

と計算される。

等変位めり込みの状態で $M$ を漸増させると、初めは部材芯をモー メント計算芯とした三角形変位めり込みの状態となり $M=2 \times M$ 三角 と計算される。また、 $x_{p}=L / 2$ である。式(4)より、

$$
\begin{aligned}
& M=2 \times M_{\text {三角 }} \\
& =2 \frac{(L / 2)^{3} y_{p} C_{y} E_{\perp} \theta}{Z_{0}} \cdot\left[\frac{1}{3}+\frac{2 Z_{0}}{3(L / 2)} \times\left(1-e^{-\frac{3 x_{1}}{2 Z_{0}}}\right)\right]
\end{aligned}
$$

モデルと等変位めり込み + 三角形変位めり込みで弾性時の $M-\theta$ 関係が等しいと仮定すると、式(18)=式(19)から、式(20)が導かれる。

$$
x=L \cdot \sqrt{\frac{1}{3}+\frac{2 Z_{0}}{3(L / 2)} \times\left(1-e^{-\frac{3 x_{1}}{2 Z_{0}}}\right)} \cdot \frac{1}{\sqrt{C_{x}}}
$$

モデルでは、離間により $M-\theta$ 関係が急変するのは、 $\delta$ が 0 となる 
ときである。そのとき、 $\Delta \delta=\delta_{\text {ini }}$ であるので、 $M=k v \times \delta_{\text {ini }} \times x \times m=$ $k v N_{i n i} / 2 m / k v \times x \times m=N_{i n i} / 2 \times x$ となる。また、バネの圧縮側では降 伏を考慮している。バネの降伏軸力は、等変位めり込みの最大変位 から求められる軸力 $N_{y}$ をバネの本数 $2 m$ で等分する。 $N_{y}$ は式(2)を式 (1)に代入することにより求められる。初期軸力により $N_{i n i} / 2 m$ が与 えらられているため、 $M_{y}=\left(N_{\max } / 2 m-N_{\text {ini }} / 2 m\right) \times x$ となる。

以上の計算を $x_{1}=x_{2}=10 \mathrm{~cm} 、 N=7.5,15,30 \mathrm{kN}$ の例に適用した結果 を図 6 に示す。解析モデルによる置換は理論式をよく表しており、 軸力が不明な場合は、離間と降伏をともに考慮しなければならない ことがわかる。理論式と解析モデルの大小関係は、軸力で異なり、 軸力が小さい場合は、同一変形角におけるモーメントが理論式>解 析モデルとなり、軸力が大きい場合は理論式＜解析モデルとなった。 この傾向は余長 $\left(x_{1}, x_{2}\right)$ が短いほど顕著であった。
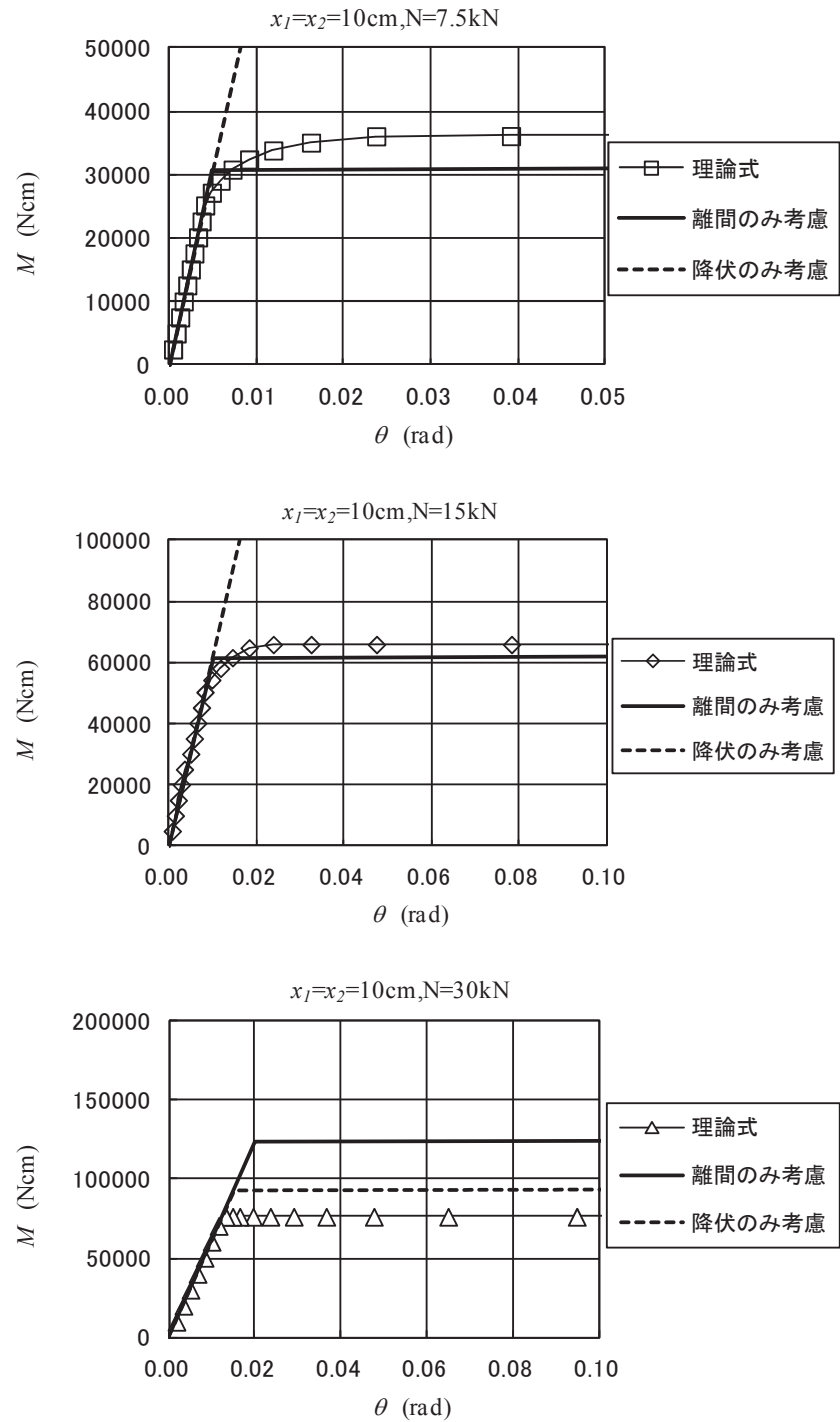

図 6 理論式と解析モデルの比較

\section{5. 木材同士のめり込みが生ずる場合のモデル化}

これまでの理論及びモデル化は木材に鋼板がめり込む場合に関す るものである。繊維方向と繊維直交方向がめり込む場合は、繊維方 向のめり込みは無視できると仮定すれば、前述したモデル化をその まま採用できる。斗と肘木のような繊維直交方向同士のめり込みの
場合は、木材の間に仮想の鋼板があると考える。相手の木材がめり 込むことにより、実際は平らな面とならないという点を除けば模擬 できるため、このモデル化手法とする。図 7 にその概要を示す。

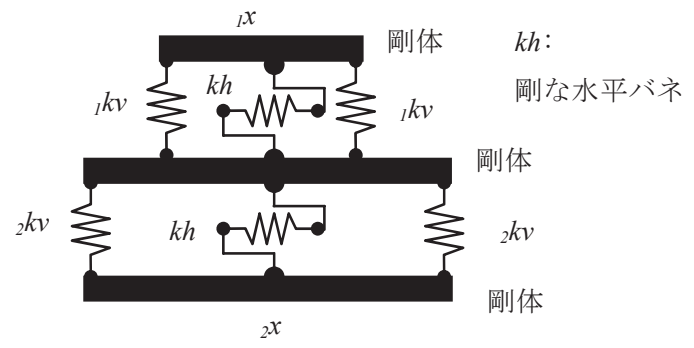

※これ以外にもねじれに関するバネが必要である。

図 7 繊維直交方向同士のめり込みの直列化

6. モーメントの加わる方向が繊維方向を軸とする場合

三角形変位めり込みは、繊維直交方向にモーメントの軸を設定し ているため、䋊維方向を軸とするモーメントに関しては、そのまま では利用できない。しかし文献 1)によれば、 $n$ 自体が、応力の広が りを数式で表現するものであるため、式(3),(4),(6),(7),(8),(9)の $Z_{0} / x_{p}$ ないし $Z_{0} / x_{p}$ の係数に $n$ がない場合は $n$ を乗じ、 $n$ がある場合はこれ を外し式を展開寸れば、式自体は異なるが、同様の結果が得られる。

\section{7. 既往の実験との比較}

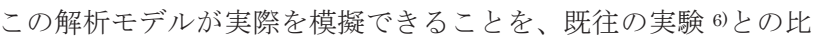
較で検証する。この実験は全てひのきを素材とし、図 8 の形状をし た斗組の桁材中央部に鉛直荷重 $(255 \mathrm{kN}, 166 \mathrm{kN})$ を加えながら、通し 肘木両端から水平載荷を繰り返し、変形角と水平荷重の関係を求め た実験である。載荷点の回転は自由となる実験装置のディテールと なっている。また、水平荷重の最大值は鉛直荷重の $0.16 \sim 0.18$ 程度 であり静止摩擦以下と考えられ、滑りやダボの影響は殆ど無視でき る実験である。実験の詳細は文献 6)を参照されたい。

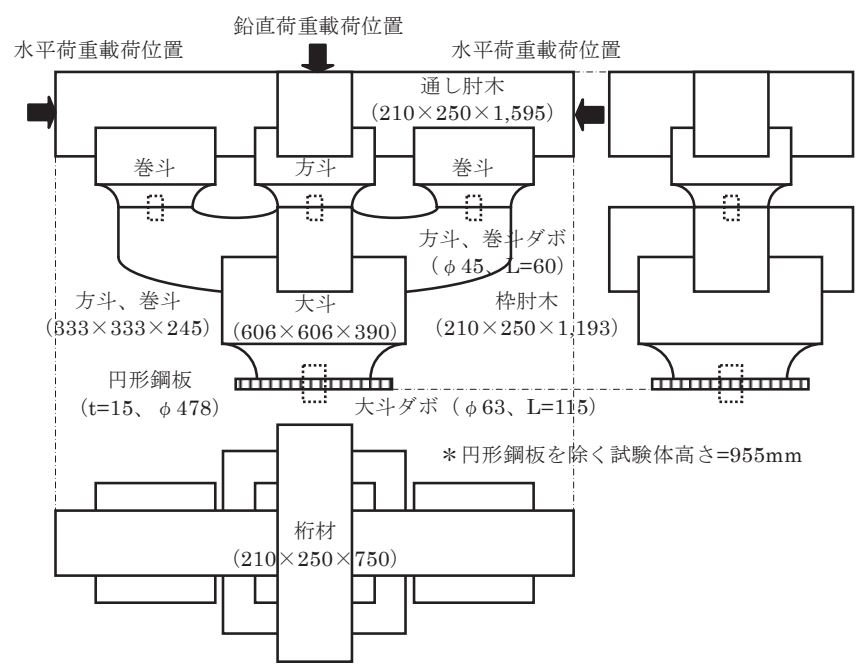

図 8 試験体外形寸法

斗のような変断面に対するめり込み式は未だ確立していないため、 敷面より上の部分の割合が最も大きい巻斗を対象として、めり込み 
バネの剛性に対する影響を、直交異方性材料のソリッド要素を用い た FEM 解析で確認した。巻斗の寸法を図 9 に示す。

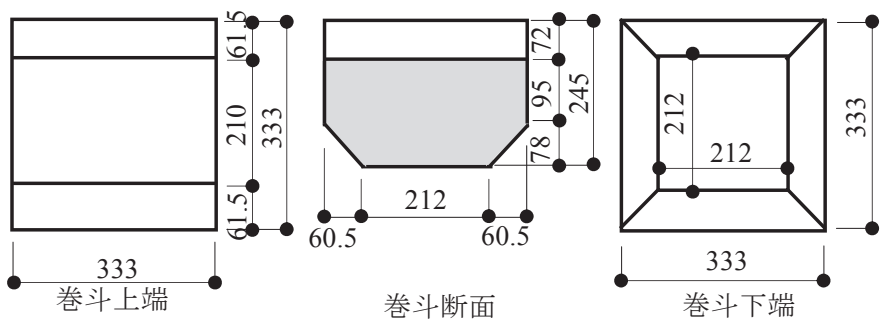

寸法単位 $\mathrm{mm}$

図 9 巻斗形状

FEM 解析では斗の突出部の影響と、斗繰の影響の程度を知るた めに、(1)巻斗の形状のモデル、(2)敷面より上の部分を除いたモデル、 (3)(2)に加え斗繰を除いたモデルの 3 モデルの敷面相当部分に等変位 の強制変位を与えた（図 10）。これは等変位めり込み基準式に対応 する状態である。モデルは全て点対称なため、1/4 モデルとし、こ れに適合した境界条件を設定した。
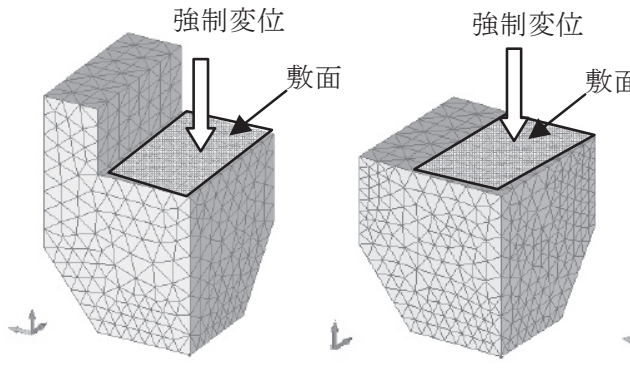

(1) 巻斗形状

\section{(2) 敷面より下のみ}

図 10 FEM 解析モデル

実験において、巻斗の繊維平行(L)方向は肘木の軸方向であること は確認されていたが、放射(R)方向と接線(T)方向は不明であった。 一般的には年輪傾角は材の中でも変動していると考えられるため、 鉛直方向を放射方向とした場合と、接線方向とした場合を解析し、 比較することとした。材料のヤング係数 $(\mathrm{E})$ 、せん断弾性係数 $(\mathrm{G})$ 、 ポワソン比 $(v)$ は、 $E_{L}=E_{0}=9000 \mathrm{~N} / \mathrm{mm}^{2} 、 E_{R}=0.075 E_{L} 、 E_{T}=0.042 \mathrm{E}_{L}$ 、 $G_{L R}=0.060 E_{L} 、 G_{L T}=0.050 E_{L} 、 G_{R T}=0.0029 E_{L} 、 \nu_{L R}=0.40 、 \nu_{L T}=0.53 、$ $v_{R T}=0.62$ とした ${ }^{5)}$ 。解析には Femap with NX Nastran ver10.2.0 を用いた。

表 2 等変位めり込み剛性（単位 $\mathrm{N} / \mathrm{mm}$ )

\begin{tabular}{|c|cc|cc|}
\hline & \multicolumn{2}{|c|}{ 鋁直方向 $=\mathrm{R}$} & \multicolumn{2}{|c|}{ 鉛直方向 $=\mathrm{T}$} \\
\hline モデル (1) & $2.79 \times 10^{5}$ & $(3.26)$ & $1.53 \times 10^{5}$ & $(1.79)$ \\
\hline モデル(2) & $2.67 \times 10^{5}$ & $(3.12)$ & $1.48 \times 10^{5}$ & $(1.73)$ \\
\hline モデル (3) & $3.10 \times 10^{5}$ & $(3.63)$ & $1.80 \times 10^{5}$ & $(2.10)$ \\
\hline めり込み基準式 & \multicolumn{3}{|c|}{$8.55 \times 10^{4}$} \\
\hline
\end{tabular}

※（）内の数值はめり込み基準式の剛性を 1 とした場合の相対值

剛性に最も大きい影響を及ぼす要因は年輪傾角であった。また、
接地面積の大きいモデル (3)はモデル(1)や(2)よりも剛性が大きい結果 となった。モデル (1)と (2)を比較すると、敷面より上の部分の有無は 等変位めり込み剛性に対する影響は小さいことがわかる。めり込み 基準式の剛性はモデル (3)の形状に沿って計算したものであるが、か なり小さい值となった。

斗は変断面のため、斗の敷面寸法で計算すると剛性が過大になり、 斗尻寸法で計算すると剛性が過小になるが、モデル(2)とモデル(3)の 差はそれほど大きくはないので、変断面の影響は考慮しないことと する。年輪傾角による差とめり込夕基準式との差異に関しては、次 ページの既存実験を模擬した鉛直荷重解析の考察において記述する。

実験を模擬する解析モデルは、部材に加え、図 11 に示すような、 斗が上、肘木が下となるめり込み面と、斗が下、肘木が上となるめ り込み面および中央の桁材と通し时木のめり込み面で構成される。 肘木の繊維直交方向の変形は、めり込みのバネで表現されるため、 剛な部材でめりこみ面と繋いでいる。また、斗の軸方向変形もめり 込みのバネで表現されるため、斗の軸方向の変形を無視できる程度 に軸剛性を上げる。大斗下部の浮き上がりの部分は、鋼板と繊維直 交方向のめり込みなので、直列化はしない。

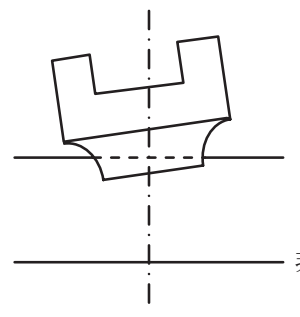

実際の斗と肘木

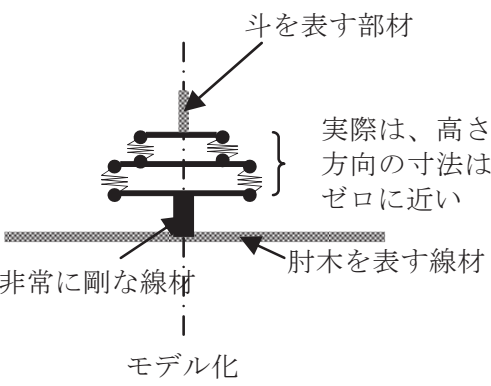

図 11 斗と肘木のめり込みおよび関連部材のモデル化
解析に用いたモデルは図 12 のような形状となった。肘木の軸方 向のヤング係数は繊維方向とし、斗の軸方向のヤング係数は繊維直 交方向とし、試験体では素材実験をしていないため、各々 9000 , $360 \mathrm{~N} / \mathrm{mm}^{2}$ とした ${ }^{5)}$ 。せん断弹性係数は、肘木は $600 \mathrm{~N} / \mathrm{mm}^{2}$ 、斗は $120 \mathrm{~N} / \mathrm{mm}^{2}$ とした。寸法以外のめり込みに関わる定数は、ひのきで あるため、 $n=6 、 F_{c v}=7.8 \mathrm{~N} / \mathrm{mm}^{2}$ とした。繰り返し水平載荷のため、 木材の挙動を再現できるよう、めり込みバネは圧縮側のみスリップ バイリニアとした。解析には Midas Gen ver7.90 を使用した。

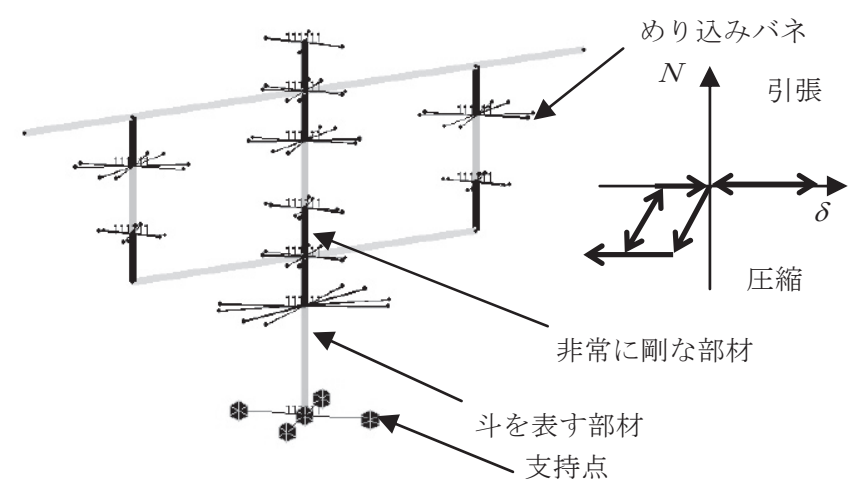

図 12 斗組実験模擬モデル 
このモデルに対し、鉛直荷重を加え弾性解析を行った。バネは全 て圧縮であり、かつ降伏耐力以下となった。実験体頂部の変位と鉛 直荷重の関係の実験結果と解析結果を図 13 に示す。

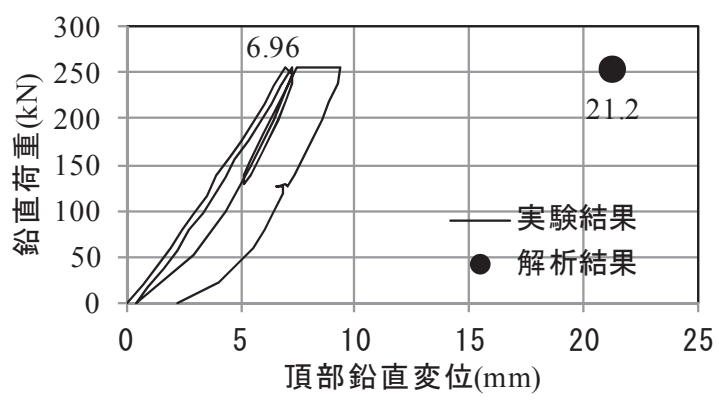

図 13 鉛直載荷実験と解析との比較

変位が実験と解析ではかなり異なったものとなっている。繊維直 交方向同士であることで 3 次元的なめり込み形状となるため、歪み の集中が起こりうること、めり込みの計算に用いる全面横圧縮ヤン グ係数 $E_{\perp}$ が、めり込み基準式では安全側となっていること、斗単 体を模擬した FEM 解析で判明しているように $E_{\perp}$ は年輪傾角でか なり変動することなどの要因が考えられる。本来であれば、これら の要因を詳細に分析した上で実験と解析の比較をすべきであるが、 上記要因は結果的に $E_{\perp}$ に影響を与えることから、 $E_{\perp}$ を一律に調整 することにより、実験と解析の整合を図った。E」を調整した結果、 3.5 倍の場合に鉛直載荷を模擬した弾性解析の最大变位が $6.99 \mathrm{~mm}$ となり、ほぼ実験と同じ変位となったため、この $E_{\perp}\left(=E_{0} \times 0.07\right)$ を以後の検討では利用した。針葉樹では、年輪の放射(R)方向のヤン グ係数 $E_{R}$ が $E_{0} \times 0.071 \sim 0.121$ 、接線 $(\mathrm{T})$ 方向のヤング係数 $E_{T}$ が $E_{0}$ $\times 0.032 \sim 0.063$ であったと報告されている ${ }^{8)} こ と 、 E_{0}$ 自体も低めの 設定の可能性が高いこと、めり込み基準式では、年輪傾角を考慮し た上で $E_{\perp}$ を小さとっているとされている1)こと、 $E_{R} 、 E_{T}$ を文献 8)の範囲内でも比較的小さい值 $\left(E_{R}=E_{0} \times 0.075 、 E_{T}=E_{0} \times 0.042\right)$ とした斗単体の FEM 解析において、めり込み剛性はめり込み基準 式の 1.79 倍〜 3.26 倍となっていることなどから、 $E_{\perp}$ の設定として 明らかな逸脱とはなっていないと考えられる。

鉛直荷重解析により得た軸力を初期軸力とし、水平荷重の繰り返 し載荷を模擬した解析を行った。大斗直下と通し时木中央を結んだ 変形角と水平荷重の関係の実験結果と解析結果を図 14 に示寸。比 較のため、鉛直荷重 $255 \mathrm{kN}$ では、ヤング係数を増加しない場合の 結果も示す。解析は実験の初期剛性および見かけ上の降伏点（実際 は離間によるもの）をよく模擬できている。ただし、実験では、変 形角が大きくなるとループを描くのに対し、解析では描いていない。 めり込み面の端部が局部的に降伏した後、変形した接触面同士のつ り合いが形成され水平荷重なしでも傾いた状態が継続することが差 異の要因として考えられる。また、解析では、圧縮側の降伏は認め られなく、離間で決定される耐力であるため、降伏に関する検証に までは至っていない。

大斗底面の挙動が支配的である旨が文献 6)に記されているため、 大斗底面のバネのみ考慮し他は剛体と考えた場合の理論式および解 析モデルによる計算と、実験結果での大斗の回転角を比較した（図 15)。理論式では、接触面の漸減による剛性の低下と最終的な降伏
による剛性の低下が見られ、その曲線は実験の包絡線とほぼ一致し ている。

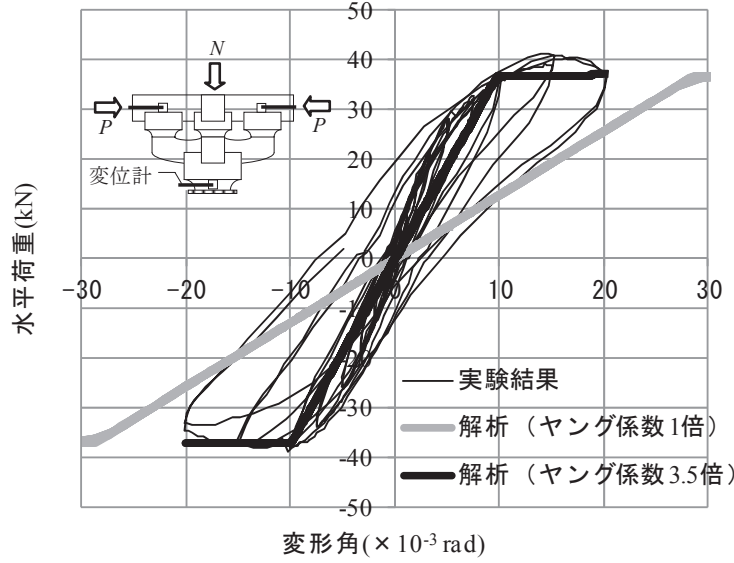

鉛直荷重 $255 \mathrm{kN}$

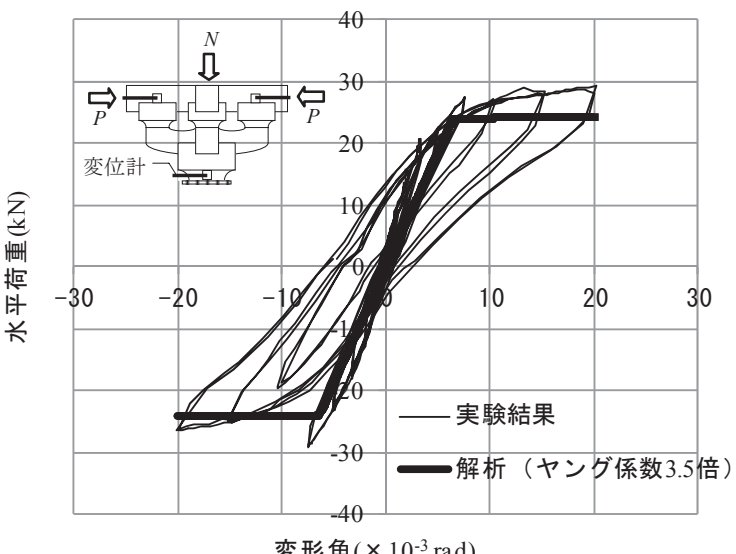

鈆直荷重 $166 \mathrm{kN}$

図 14 水平載荷実験と解析との比較

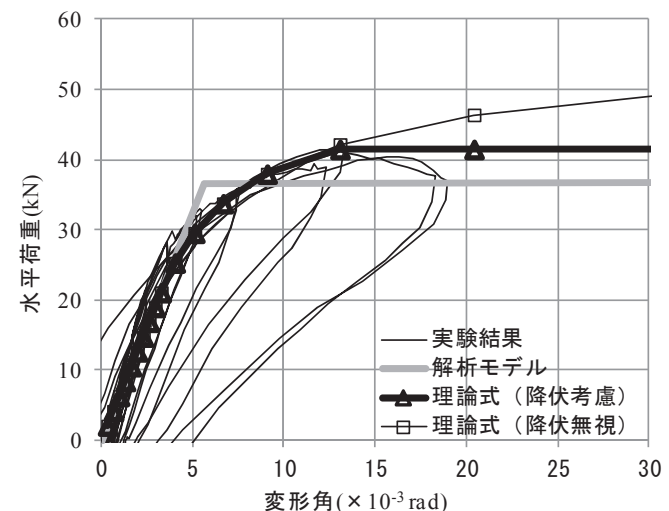

図 15 実験,理論式,解析モデルの比較（大斗回転, $255 \mathrm{kN}$ )

鉛直荷重 $255 \mathrm{kN}$ の場合の原点近辺の拡大図を図 16 に示寸。解析 の初期剛性は、実験の最初期の剛性の 7 割程度となっている。図 15 を拡大した図 17 でも理論式、解析モデルともに 7 割程度と同様の 傾向を示した。傾斜復元力の影響などが考えられるが、原因の特定 までには至らなかった。 


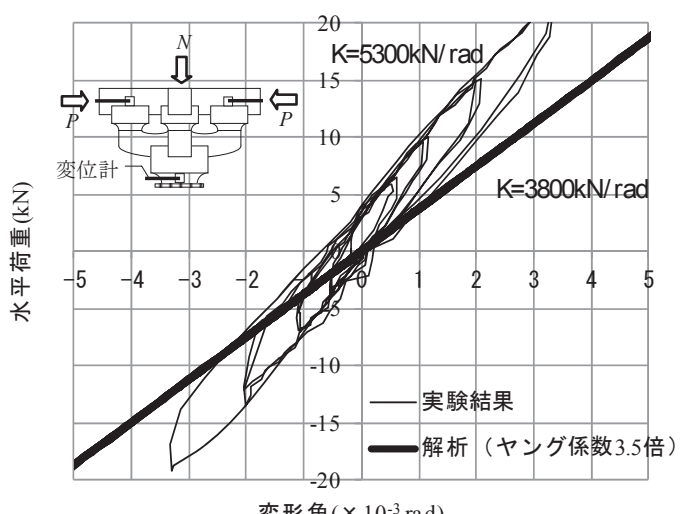

変形角 $\left(\times 10^{-3} \mathrm{rad}\right)$

図 16 水平載荷実験と解析との比較（拡大図、255kN）

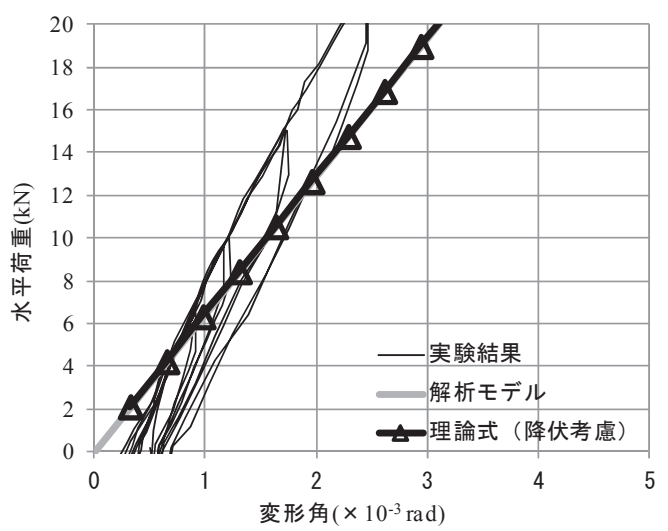

図 17 実験,理論式,解析モデルの比較 (拡大図,大斗回転, $255 \mathrm{kN}$ )

実験と解析の水平変形モードを図 18 に示す。文献 6)では、大斗 のすべりを除いた変形は、大斗底面の弾塑性変形により集約し得る と考察されているが、解析においても、特に正加力方向において、 その状況を再現できている。

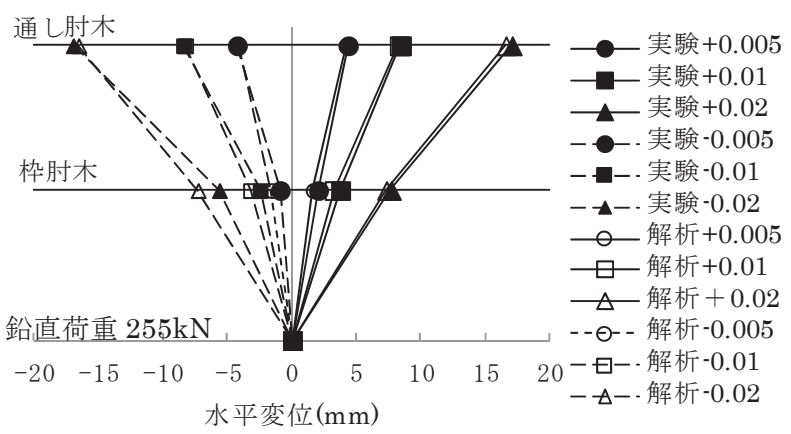

図 18 水平載荷実験と解析との比較（水平変形モード）

8. 結

稲山のめり込み理論から、離間と降伏を考慮した木材のめり込み の算定式を導き、一般的な解析ソフトでも利用できる簡易なモデル 化手法を提案した。その際に以下を仮定している。

(1) 等変位めり込みの $x_{1}$ と $x_{2}$ を等しいものとして計算する。

(2) めり込夕面は平らな面を保持するものとする。

(3) 降伏変位、降伏角度に達した後の二次剛性は剛性ゼロと寸る。

(4) 水平力は静止摩擦力以下である。
また、モデル化手法に基いたモデルを作成し、斗組に関する既往 の実験との比較を行った。䋊維直交方向ヤング係数を確定できれば、 剛性と離間に関しては実験を模擬でき、応力解析に利用できること を示した。また、実験での大斗の回転に関しては、理論式によりほ ぼその包絡線を模擬できた。ただし、以下のような課題が残ってい る。(1)軸力に応じ、理論式と解析モデルの最大モーメントに違いが 生ずる (2)簡易なモデルのため、めり込み面の局部的な降伏変形に よる接触面の変形に伴うと考えられる残留変位までは模擬できなか った。(3)最初期の剛性に関しては実験と理論式、解析モデルで差異 が生じたが、その原因の特定には至らなかった。

今後の課題としては、上記の課題に加え、降伏後の剛性の考慮と、 稲山のめり込み理論以外一の拡張、接触面の変形の考慮、静止摩擦 を超えた場合の挙動の考慮、ダボの考慮などが考えられる。

\section{謝辞}

本研究のために、貴重な実験データを拠出して頂いた竹中工務店 技術研究所の楠寿博主任研究員之竹中工務店大阪本店の長瀬正 PE に深く感謝いたします。

参考文献

1）稲山正弘：木材のめり込夕理論とその応用, 東京大学学位論文, 1991

2）棚橋秀光, 大岡優, 伊津野和行, 鈴木祥之 : 木材のめり込み降伏メカニ ズムと均等めり込み弾塑性変位の定式化, 日本建築学会構造系論文集, vol76,No.662,pp.811-819,2011.4

3）棚橋秀光, 鈴木祥之：伝統木造仕口の回転めり込み弾塑性特性と十字型 通し貫仕口の定式化, 日本建築学会構造系論文集, vol76, No.667, pp.1675-1684, 2011.9

4）荒木康弘, 腰原幹雄, 五十田博, 河合直人, 坂本功 : 木造住宅の接合部 破壊を考慮した大変形時の静的挙動に関寸る解析的研究，日本建築学会 構造系論文集, vol74,No.637,pp.527-535,2009.3

5）日本建築学会：木質構造基礎理論,pp.97-103,2010

6）楠寿博, 長瀬正, 木林長仁，林良彦，植田哲司：伝統木造建築における 斗組の構造特性に関する実験的研究, 日本建築学会構造系論文集, No.592,pp.129-136,2005.6

7) 飯島泰男 : 木構造設計資料 WB-3 構造用製材の強度と等級区分, 日本住 宅・木材技術センター, pp.3-4,1991

8) 山井良三郎：木材の圧縮異方性について，日本林学会誌，39(9), pp.328-338,1957.9

(2011年10月 6 日原稿受理，2012年 6 月27日採用決定） 